\title{
WÜRTTEMBERŠKI GORSKI BATALJON IN 12. SOŠKA OFENZIVA
}

\author{
WÜRTTEMBERG MOUNTAIN BATTALION \\ AND THE TWELFTH ISONZO OFFENSIVE
}

Povzetek Württemberški gorski bataljon je bil nemška vojaška enota dežele Württemberg. Oblikovan je bil precej pozno, šele oktobra 1915. Enota, ki ji je poveljeval major Theodor Sprösser, je prevzela pomembno vlogo v 12. soški ofenzivi, saj je ves čas delovala $\mathrm{v}$ konici napada alpskega korpusa in pozneje 1. avstro-ogrskega korpusa Krauss. Pomembno vlogo znotraj bataljona je imel tudi nadporočnik Erwin Rommel, ki je skupaj z majorjem Sprösserjem prejel visoko odlikovanje pour le mérite za uspešne boje ob reki Soči v prvih dneh ofenzive in operacijo Longarone. Bataljon je ves čas prodora od Tolmina do reke Piave deloval decentralizirano na več samostojnih smereh, saj so njegovi častniki razumeli in obvladali načelo poveljevanja s poslanstvom (Auftragstaktik) ter obvladali veščine nove taktike prodora. Bataljon je bil decembra 1917 skupaj z drugimi enotami 14. armade premeščen z italijanske fronte na opravljanje nove bojne naloge.

Ključne Prva svetovna vojna, soška fronta, 12. soška ofenziva, Württemberški gorski besede bataljon, Theodor Sprösser, Erwin Rommel.

Abstract The Württemberg Mountain Battalion was a German military unit of the Kingdom of Württemberg. It was formed relatively late, only in October 1915. The unit, which was commanded by Major Theodor Sprösser assumed a very important role in the Twelfth Isonzo Offensive. It was continuously engaged in the peak of the attack by the Alpine Corps' (Alpenkorps) and later $1^{\text {st }}$ Austro-Hungarian corps Krauss. An important role within the battalion was also played by First Lieutenant Erwin Rommel, who was together with Major Sprösser awarded a decoration Pour le Mérite for his success in the battles near the Isonzo River in the first days of the offensive, and for the Longarone operation. Throughout the penetration from Tolmino to the Piava River, the battalion functioned in a decentralised manner on several independent routes, since the commanders understood and mastered the mission command 
(Auftragstaktik) and mastered the skills of the new penetration tactics. In December 1917, the battalion and other units of the $14^{\text {th }}$ Army were redeployed from the Italian front to a new combat assignment.

\section{Key words First World War, Isonzo Front, Twelfth Isonzo Offensive, Württemberg Mountain Battalion, Theodor Sprösser, Erwin Rommel.}

Uvod 12. soška ofenziva, ki jo poznamo tudi kot čudež pri Kobaridu, preboj pri Kobaridu ali polom pri Kobaridu, je gotovo eden najbolj znanih vojaških spopadov na slovenskem ozemlju, ki še danes vzbuja zanimanje vojaške in civilne strokovne javnosti. Po začetku ofenzive 24. oktobra 1917 je 14. armadi skupaj z avstro-ogrskimi zavezniki uspelo hitro zavzeti italijanske obrambne črte. Italijanska vojska, še posebej pa 2. armada, ki je doživela velike izgube in se znašla v kaosu ter komunikacijskem mrku, je bila potisnjena v Furlansko nižino na reko Tilment in nato na reko Piavo, kjer se je prodor centralnih sil 10. novembra 1917 tudi ustavil. Nemško cesarstvo in avstro-ogrska monarhija sta tako dosegla najpomembnejša strateška cilja - oslabitev italijanske armade in stabilizacijo tedaj že bistveno krajše jugozahodne fronte. V 14. armado so bile vključene številne nemške enote, med katerimi je v okviru alpskega korpusa znotraj skupine Stein deloval tudi Württemberški gorski bataljon, ki je imel pomembno vlogo pri preboju frontne črte pri Tolminu.

\section{USTANOVITEV IN SESTAVA BATALONA}

Württemberški gorski bataljon je bil nemška vojaška enota dežele Württemberg. Oblikovan je bil precej pozno, in sicer oktobra 1915. Predhodnik tega bataljona je bila smučarska četa, ki je bila maja 1915 preimenovana $\mathrm{v}$ gorsko četo in oktobra vključena $\mathrm{v}$ bataljon. Glavna zamisel oblikovanja Württemberškega gorskega bataljona je bila, da bo vsaka izmed šestih gorskih čet sposobna samostojnega delovanja ob podpori ene izmed treh čet mitraljezov. Poveljevanje bataljonu je prevzel major Theodor Sprösser, izkušen častnik, ki je pri 48 letih vodil bataljon tudi v 12. soški ofenzivi. Ob oblikovanju Württemberškega gorskega bataljona sta bila prva cilja poveljnika bataljona majorja Sprösserja poleg vzpostavitve organizacijske strukture in opremljanja tudi učinkovitost in morala (Wilks, 2001, str. 19-20). Moto Württemberškega gorskega bataljona neustrašnost in zvestoba (Sprösser, 1933, str. 42) je poudarjal vrednoti, ki sta bili pomembni za moralni del vojskovalne moči. To se je obrestovalo v 12. soški ofenzivi, v kateri so njegove čete sledile svojim poveljnikom na zahtevnem gorskem terenu.

K Württemberškemu gorskemu bataljonu so na dan začetka ofenzive 24. oktobra 1917 spadali poveljstvo bataljona, šest gorskih čet in tri čete mitraljezov. Dodani so bili še dve manjši poveljstvi odredov in četa zvez. Bataljon je bil okrepljen tudi z minometno in učno četo, ki sta ostali v Beljaku in nista šli z bataljonom v ofenzivo. Poveljnik bataljona je v 12. soški ofenzivi poveljeval desetim četam, kar je bila zahtevna naloga, saj so enote delovale na ločenih smereh, zato je major Sprösser 
znotraj bataljona oblikoval tri odrede ${ }^{1}$, ki so lahko delovali samostojno. Eden izmed poveljnikov odredov je bil tudi nadporočnik Erwin Rommel. Poveljnik bataljona je velikost odredov oblikoval glede na razmere in nalogo. V veliko publikacijah so nejasnosti zaradi napačnega prevajanja nemške besede Abteilung. To je tudi vzrok, zakaj je Rommel naveden kot poveljnik čete, skupine, oddelka in celo bataljona (Sprösser, 1933, str. 346).

Oblikovanje odredov v bataljonu je imelo veliko prednost, ker je bataljon lahko deloval decentralizirano na več samostojnih smereh. Pogoj za tak koncept so bili usposobljeni častniki, ki so razumeli in obvladali načelo poveljevanja s poslanstvom (Auftragstaktik) ${ }^{2}$ in obvladali veščine nove taktike prodora. ${ }^{3}$ Württemberški gorski bataljon je namreč pomembne izkušnje v taktiki prodora pridobil že na zahodni fronti (Visoki Vosges). Francozi na tem hribovitem predelu niso imeli strnjene obrambne črte, temveč posamezne odporne točke za krožno obrambo. To je Württemberškemu gorskemu bataljonu omogočalo uporabo taktike vrinjenja in napade $\mathrm{z}$ boka ter hrbta (Bull, 2014, str. 86).

V Württemberškem gorskem bataljonu so tudi poudarjali omogočanje svoje ognjene moči. V treh mitraljeških četah so imeli skupno 18 mitraljezov MG-08, v šestih pehotnih četah pa 36 puškomitraljezov MG-08/15. To je bilo dovolj za veliko koncentracijo ognja in lokalno premoč nad nasprotnikom. Na italijanski strani so imeli v bataljonu 14 puškomitraljezov (Gaspari, 2013, str. 29), kar je pomenilo skoraj trikratno premoč na nemški strani. Puškomitraljezi so se skupaj z mitraljezi odlično dopolnjevali, saj so puškomitraljezi prišli do izraza s hitro premičnostjo, mitraljezi pa z neposredno podporo enotam tudi na večjih razdaljah. Artilerija je z različnimi kalibri in izjemnim ešaloniranjem ognja zagotavljala največjo mogočo podporo jurišnim enotam v neposredno bližino nasprotnika.

\footnotetext{
Nemško Abteilung, angleško detachment.

2 Auftragstaktik - gre za prednostno načelo poveljevanja in nadzora v vojski. Temelji na medsebojnem zaupanju in pomeni za vsakega vojaka neomajno obvezo opravljanja svojih dolžnosti. Vojaški voditelj obvešča o svoji nameri, postavlja jasno dosegljive cilje ter zagotavlja sile in sredstva. Auftragstaktik so v angleščino prevedli z besedama mission command, ki pomenita uporabo avtoritete poveljnika pri usmerjanju delovanja prek jasnega poslanstva ter spodbujanje disciplinirane pobude znotraj njegove namere in omogočanje razvoja delavnih ter prilagodljivih podrejenih poveljnikov za izvajanje združenih kopenskih operacij.

3 Prodor - v vojaški taktiki pomeni način napada, pri katerem poskuša napadalec doseči položaje nasprotnika $v$ globini njegovega bojnega razporeda na eni ozki smeri ali več ozkih smereh hkrati. Napadalec poskuša pred prodorom najti ali ustvariti šbke točke v nasprotnikovem obrambnem sistemu in se izogiba močno utrjenim predelom. Glavna zamisel prodora je v najkrajšem mogočem času doseči globino nasprotnikovega bojnega razporeda, po možnosti brez boja. Kritičen del pri manevru prodora je zaščita svojih sil, kar napadalci dosežejo s čim večjo hitrostjo prodora. To je bila in je še vedno ena temeljnih oblik pehotnega manevra. V teoriji vojaške taktike ločimo tri vrste prodora, in sicer globoki, večsmerni in kombinirani prodor.
} 


\section{PREMIK WÜRTTEMBERŠKEGA GORSKEGA BATALJONA NA SOŠKO BOJIŠČE}

Württemberški gorski bataljon ${ }^{4}$ je bil na začetku priprav na 12. ofenzivo septembra 1917 v Dravski dolini na Koroškem še del 1. avstro-ogrskega korpusa Krauss. Poveljnik 14. armade general Otto von Below je 28. septembra v Kranjski Gori predstavil načrt preboja na pomožni smeri Bovec-Žaga-Stol, v katerega je bil vključen tudi Württemberški gorski bataljon. Ta se je na podlagi tega ukaza začel takoj pripravljati za premik v smeri Beljak-Kranjska Gora-Vršič-Trenta na izhodiščno območje napada severno od Bovca (Sprösser, 1933, str. 260).

Že dober teden pozneje, 6. oktobra 1917, je Württemberški gorski bataljon obiskal poveljnik 14. armade general von Below s svojim pribočnikom. Na gradu Wernberg na Koroškem je poveljnika Württemberškega gorskega bataljona majorja Sprösserja seznanil z ukazom o prerazporeditvi njegovega bataljona iz korpusa Krauss v alpski korpus, kar je pomenilo, da bo bataljon prebijal frontno črto pri Tolminu (Sprösser, 1933, str. 261). Pripadniki Württemberškega gorskega bataljona so novico sprejeli z mešanimi občutki, saj so se še vedno spominjali spopadov v Romuniji na gori Magura Odobesti (1001 m), kjer so se januarja 1917 bojevali pod poveljstvom alpskega korpusa skupaj s polkom Leib (Reiss, 1931, str. 253-263).

Ne glede na vse so pripadniki bataljona usmerili svojo pozornost v izvedbo nove dodeljene naloge, kajti do 10. oktobra je bilo treba bataljon pripraviti za premik na širše območje Radovljice. Prav zato je 9. oktobra major Sprösser izdal ukaz za premik Württemberškega gorskega bataljona s Koroške na širše območje Radovljice v dveh skupinah, in sicer odred Rommel v sestavi 1., 2. in 3. gorske čete, 1. mitralješke čete, čete za zveze ter minometne čete, odred Gössler pa v sestavi 4., 5. in 6. gorske čete ter 2 . in 3. mitralješke čete.

Iz arhivskih dokumentov je razvidno, da je imel Württemberški gorski bataljon razmeroma malo časa za načrtovanje napada. $\mathrm{V}$ primerjavi s polkom Leib major Sprösser ni imel možnosti, da bi še pred pohodom izvidoval Tolminsko kotlino. Odvisen je bil od podatkov, ki jih je dobil 11. oktobra od polka Leib na Bohinjski Beli. Od sprejema pripravljalnega povelja do odhoda proti Tolminu je imel še štiri dni, izdaja ukazov pa je potekala tudi med pohodom. 12. oktobra je Württemberški gorski bataljon prišel na Gorenjsko in začelo se je razmeščanje njegovih enot po krajih na Gorenjskem. Poveljstvo Württemberškega gorskega bataljona je bilo v Radovljici, odred Rommel je bil v Zgornjem in Spodnjem Otoku, Gorici ter Vrbnjah, odred Gössler pa v krajih Ljubno in Podbrezje. Prvi bataljonski ukaz (HStAS, 2) je bil kratek pripravljalni ukaz za napad in premik enot. V njem so bili navedeni poveljniki in najpomembnejši častniki poveljstva 14. armade ter poveljstva alpskega korpusa. Oddati so morali vsa vozila in za nadaljevanje transporta je bila odobrena le uporaba tovornih živali. Pod ukazom je bil podpisan major Sprösser kot poveljnik tretje pohodne skupine. Izdan je bil tudi podrobnejši ukaz za pohod tretje pohodne

${ }^{4}$ Pot 14. armade in Württemberškega gorskega bataljona je prikazana na zemljevidu št. 1 . 
skupine (HStAS, 1). V sedmih točkah so opredeljeni območja razmestitve enot pred pohodom in načrt pohoda do Stare Loke pri Škofji Loki. Pohodi so skladno s splošnim ukazom 14. armade potekali le ponoči in z ustreznimi časovnimi zamiki.

14. oktobra so bila izdana tudi navodila (HStAS, 3) glede prerazporejanja tovornih živali in prevzema nekaterih materialnih sredstev. V navodilih je bil naveden spisek opreme, ki so jo enote Württemberškega gorskega bataljona morale prevzeti 15 . oktobra ob 10. uri v vasi Otok in istega dne ob 15. uri v bataljonskem skladišču na železniški postaji Podnart-Kropa. Iz časovnice je razvidno, da so sredstva prevzemali na dan, ko se je zvečer začel pohod. Major Sprösser je nato izdal ukaz za pohod tretje pohodne skupine v smeri Radovljica-Škofja Loka-Kneža. 15. oktobra ob 17. uri je odred Rommel začel s pohodom v smeri Otok-Mošnje-Podbrezje-Zgornja Bistrica-Spodnja Bistrica-Britof, kjer so počivali. Za 16. oktober je bilo ukazano nadaljevanje pohoda $\mathrm{v}$ smeri Naklo-Kranj-Žabnica. V okviru tretje pohodne skupine so bile oblikovane še tri podskupine, ki so imele načrtovan pohod v treh časovnih intervalih. Nadporočnik Rommel je imel s svojim štabom in polovico Württemberškega gorskega bataljona določen začetek pohoda ob 18. uri. Stotnik Gössler z drugo polovico Württemberškega gorskega bataljona, baterijo gorskih havbic 17 in gorskim odredom za zveze 311 je imel ukazan začetek pohoda ob 18.30. Ob 19.15 je bil določen začetni čas pohoda za odred gorske artilerije 4, sanitetno četo 201 in terensko bolnišnico 44.

Z ukazom je bil določen tudi polurni odmor pred severnim vhodom v Kranj. Za sprejem naslednjega ukaza je bila določena železniška postaja v Kranju, in sicer 16. oktobra ob 19. uri. Istega dne ob 17. uri se je nadaljeval pohod Württemberškega gorskega bataljona v smeri Bistrica-Naklo-Kranj-Škofja Loka. Poveljstvo Württemberškega gorskega bataljona se je namestilo za prenočevanje v Škofji Loki, čete pa v krajih Spodnje Bitnje, Žabnica in Sveti Duh. 17. in 18. oktobra je sledil počitek, potem pa jih je 19. oktobra čakal težak pohod v temi in dežju po Selški dolini v smeri Škofja Loka-Železniki-Zali Log. V Zali Log so prišli pozno ponoči in čete Württemberškega gorskega bataljona so se namestile po hlevih, senikih in hišah. Naslednji dan je sledil pohod v smeri Zali Log-Petrovo Brdo-Podbrdo-GrahovoKneža, tako da je 21. oktobra v zgodnjih nočnih urah Württemberški gorski bataljon prispel na Knežo. Enote so se namestile v gorski koči nad železniško postajo, poveljstvo pa južno od železniške postaje Kneža. Prehrano so imeli na železniški postaji Kneža. Istega dne so Sprösser, Rommel, Schiellein, Wahrenberger in Gössler šli na ogled izhodiščnih položajev severnega pobočja Bučenice. Med premikom jih je oviral italijanski artilerijski ogenj, ki je bil koncentriran na območje med Bačo pri Modreju in Sv. Lucijo (danes Most na Soči). Že med ogledom območja Bučenice so ocenili, da bo razmestitev enot zelo zahtevna zaradi delno poraščenega strmega skalnega pobočja, ki ga prekinjajo ozke grape. Največje tveganje za Württemberški gorski bataljon so bile italijanske opazovalnice na Mrzlem vrhu (1360 m), ki so imele ob dobri vidljivosti odprt pogled na to območje, usmerjeni artilerijski ogenj na strmo skalno pobočje pa bi lahko povzročil veliko žrtev. Poveljujoči v Württemberškem gorskem bataljonu so se zavedali, da bo največji izziv, kako naj prikrijejo enote 
in kako pomembna bo pri tem maskirna disciplina, saj se bodo na tem območju zadrževali več kot 30 ur. Istega dne je 1. bavarska lovska brigada, v sestavi katere sta bila tudi Württemberški gorski bataljon in polk Leib, dobila ukaz z določenimi cilji. Kot glavni cilj napada za 1 . bavarsko lovsko brigado je bil s tem ukazom določen Matajur (HStAS, 4).

22. oktobra so enote končale priprave na Kneži in se zvečer premaknile na izhodiščne položaje na pobočje Bučenice, kamor so prispele okrog polnoči. Med pohodom so jih ovirali močni žarometi z italijanskih položajev na Kolovratu in Ježi ter pogost artilerijski ogenj. To jih je prisililo v večkratno, nekaj minut dolgo nepremično ležanje na premočenih tleh (Rommel, 1997, str. 10). Tovorne živali so pustili na vzhodnem pobočju Bučenice, preostale enote pa so prispele na izhodiščno območje 23. oktobra nekaj po polnoči. Do jutra so se vkopavali približno 500 metrov severovzhodno od vrha Bučenice $(510 \mathrm{~m})$. Zaklonilnike za enega ali dva vojaka so prekrili z vejami. Vojaki v enotah so tako zakriti in premočeni čez dan poskušali malo spati. Rommel opisuje, da se je dan vlekel v neskončnost, spali pa so zaradi italijanskih artilerijskih napadov zelo malo. Na njihovo srečo je v bližino njihovih položajev padlo le nekaj granat (Rommel, 1997, str. 11). Zvečer so s tovornimi živalmi prinesli enotam hrano na položaje, potem pa so prinesli še dodatno strelivo. Izkušnje iz predhodnih spopadov v gorah so namreč opozarjale na številne težave, ki so nastale zaradi pomanjkanja streliva. Po polnoči 24. oktobra je spet začelo deževati. Rommel je ob tem zapisal: »Vreme, kot naročeno za napad!« (1997, str. 12; HStAS, 5).

Rommel opisuje pohod v Baško grapo kot zahtevno in naporno nalogo (zemljevid št. 1, str. 96). Vse se je dogajalo ponoči, večinoma v močnem dežju, podnevi pa so bili prikriti po vaseh. Nastanjeni so bili v kmečkih hišah, hlevih in senikih. Hrana je bila skromna in enolična, vendar je bilo razpoloženje v enoti kljub temu odlično (1997, str. 12). Če se ozremo nazaj na zadnjih 30 ur pred začetkom napada, si lahko le predstavljamo, v kakšnih razmerah so delovale enote Württemberškega gorskega bataljona. To kaže na njihovo izjemno fizično in psihično pripravljenost. Dež, mraz, premočena obleka in pomanjkljiva prehrana so bili velik preizkus pripravljenosti, vzdržljivosti ter discipline. Zaradi mraza, dežja in bivanja na prostem je vojake ogrožala tudi podhladitev, še posebno ker so bili obroki hrane zmanjšani in se $\mathrm{z}$ gibanjem niso mogli ogreti. Enote Württemberškega gorskega bataljona so se zavedale pomena moralne komponente vojskovalne moči. Rommel jo opisuje tako: »Preskrba je bila skromna in enolična, vendar je bilo razpoloženje kljub vsemu odlično. Enote so se v treh letih vojne naučile prenašati trdo življenje, ne da bi pri tem izgubljale prožnost.« (1997, str. 12).

\section{VLOGA ERWINA ROMMLA PRI PREBOJU FRONTE PRI TOLMINU IN BOJ WÜRTTEMBERŠKIH ČASTNIKOV ZA UGLEDNA ODLIKOVANJA}

Alpski korpus, v katerem je deloval tudi Württemberški gorski bataljon, je imel nalogo zavarovati levi bok korpusa Stein, osvojiti Kolovrat in območje izvira reke Idrija ter odpreti pot po dolini Nadiže. Izhodiščni položaji oziroma točke zbiranja 
enot so bile na Bučenici in pod njo ter na Mengorah. Naloga württemberške elitne formacije je bila, da prodira desno od bavarskega polka Leib po severnem pobočju Hlevnika proti zaselku Foni, kjer naj bi uničila italijanske baterije, potem pa naj bi sledila bavarskemu polku Leib po Kolovratu proti vrhu Matajurja.

Napad se je začel 24. oktobra 1917 ob 8. uri ${ }^{5}$ (zemljevid št. 2. str. 96), in sicer v smeri proti Volčam oziroma volčanskemu polju s cerkvijo svetega Danijela. Na levem krilu 1. bavarske lovske brigade je bil 1. bavarski lovski polk, 2. bavarski lovski polk je bil v rezervi, v sredini bavarski polk Leib, na desnem krilu pa Württemberški gorski bataljon. Gozd, megla in dež so nemške enote zakrivali pred italijanskimi opazovalci. Odred Württemberškega gorskega bataljona s približno 200 vojaki je vodil tudi nadporočnik Erwin Rommel, ki je vojaško pot svoje enote opisal v knjigi Pehota napada.

Nadporočnik Rommel je prvotni načrt preboja Württemberškega gorskega bataljona bistveno spremenil in izkoristil svoji drznost in pobudo ter prednost terena (slika 1 in 2 na str. 97). Rommel je s svojim odredom v okviru Württemberškega gorskega bataljona deloval na taktični ravni, kar je imelo vpliv tudi na operativni ravni. Če se osredotočimo na bitke na Kolovratu in zasedbo Matajurja, je Rommel izstopal v taktičnem smislu ne toliko z osvojitvijo Matajurja, temveč s svojim prodorom 25. oktobra na grebenu Kolovrata. S to svojo zamislijo o prodoru na mirnejšem odseku fronte je sprostil zapleten položaj okrog kote 1114 in tako pridobil taktično prednost pred Italijani, ki so uvajali taktično rezervo na greben Kolovrata. Iz zapisov in poročil je razvidno, da sta imela Rommel ter Sprösser trden odnos medsebojnega zaupanja. Med njima je bila sicer po letih generacijska razlika, saj je bil Sprösser kar 20 let starejši od Rommla. Dejstvo je, da je bil Sprösser odličen in izkušen poveljnik bataljona, ki je znal vzgajati svoje častnike ter jih postaviti na prava poveljniška mesta. Nadporočnikom je dajal odgovorne naloge poveljnika čete in odreda, kar je $\mathrm{v}$ praksi pomenilo vodenje enot skoraj na ravni bataljona. Kot mentor in svetovalec jih je neposredno na bojiščih pripravljal na sprejem odgovornejših nalog. Znal je oceniti tudi njihov značaj in uporabiti njihove prednosti, zato ne preseneča, da je dodelil motiviranemu nadporočniku Rommlu odgovorne ter tudi tvegane naloge $\mathrm{v}$ konici napada ne le na soški fronti, temveč tudi na drugih bojiščih. Vedel je, da ima Rommel dovolj samozavesti in znanja za samostojno razmišljanje ter odločanje tudi v najtežjih razmerah. Rommel je Sprösserja spoštoval in upošteval njegove usmeritve. Delovala sta po načelih vodenja in poveljevanja Auftragstaktik ter razumela, kaj pomeni disciplinirana pobuda. Sprösser je bil prvi mentor, ki je odločilno vplival na Rommlov strokovni razvoj. Kako zelo je cenil Rommla, se jasno vidi iz stavka, ko opisuje uspešen napad Rommla in njegovega odreda na Matajur: »Neverjeten dosežek poveljnika (Rommla), sijajno tako zaradi neumorne predanosti in drznosti kakor tudi zaradi samostojnosti in spretnosti.« (1933, str. 285).

Ob podpori majorja Sprösserja se je Rommel v samo 52 urah po začetku ofenzive s svojo enoto povzpel na Matajur. Pri tem je zajel 150 italijanskih častnikov, 9000

${ }_{5}$ Podrobnejši opis bojev Württemberškega gorskega bataljona 24. oktobra 1917 je prikazan na zemljevidu št. 2. 
italijanskih vojakov in 84 topov. V Rommlovih enotah je bilo v treh dneh ofenzive šest mrtvih in trideset ranjenih. Zanimiv je podatek, da sta bila tako poveljnik bataljona major Theodor Sprösser kot tudi poveljnik odreda nadporočnik Erwin Rommel za uspehe v bojih na Soči in za uspešno zajetje umikajoče se italijanske divizije pri mestu Longarone odlikovana z vojaškim odlikovanjem pour le mérite (modri maks), ki jima ga je podelil nemški cesar (Rommel, 1997. str. 61-62). Pot do tega odlikovanja je bila za württemberška častnika težka. Pri tem ju niso ovirale le vojaške ovire v ožjem pomenu besede, temveč težave pri dokazovanju njunih uspehov. Za württemberške vojaške gornike je namreč veljalo, da so jim bile v nemških enotah dodeljene naloge, ki so obetale vojaški uspeh in priznanje. 12. soška ofenziva ni dajala priložnosti le Württemberžanom, temveč tudi drugim enotam nemških držav, med katerimi je prevladovala velika tekmovalnost. Pri tem je treba poudariti predvsem tekmovalnost med Württemberžani in Bavarci. Izhodiščni položaj Württemberškega gorskega bataljona iz dežele Württemberg v sestavi alpskega korpusa je bil neugoden, saj mu je poveljeval bavarski poveljnik generalmajor Ludwig von Tutschek, korpus pa je bil dodeljen skupini Stein, ki ji je prav tako poveljeval bavarski general. Za Württemberžane je bilo nevarno, da bodo za druge enote, predvsem bavarske, morali opravljati pomožne naloge, kar se je izkazalo že v bojih v Romuniji pozimi leta 1916 in 1917. Bojazen, da bodo Württemberžani degradirani, je bila velika, kar se je kmalu po začetku bojev tudi izkazalo, ko sta se Sprösser in Rommel sprla z bavarskim pehotnim polkom Leib. Nesoglasje se je povečalo pod koto 1114 (Na Gradu), pomembnim italijanskim višinskim položajem, ki ga je bilo treba zavzeti med vzponom na greben Kolovrat. Poveljnik bavarskega polka Leib major Graf Bothmer je Rommlu in njegovemu odredu zvečer 24. oktobra 1917 prepovedal izvajati ofenzivne aktivnosti na tem višinskem položaju. Namen prepovedi je bil, da si bavarske enote z osvojitvijo kote 1114 pridržijo ekskluzivno možnost za pridobitev vojaških odlikovanj. Načrt je bil uspešen, saj je poveljniku 12. čete pehotnega polka Leib poročniku Ferdinandu Schörnerju, ki je postal med drugo svetovno vojno podobno kot Rommel feldmaršal, uspelo vzpostaviti nadzor nad italijanskim višinskim položajem, za kar je bil tudi odlikovan z odlikovanjem pour le mérite (Mährle, 2009. str. 30-31).

Ko je Rommlov odred 26. oktobra 1917 uspešno osvojil Matajur, se je pokazala še dodatna nepričakovana težava. Rommel je upal, da bo za svoj dosežek podobno kot Schörner odlikovan s pour le mérite, v resnici pa je general Otto von Below, ki je za osvojitev Matajurja prav tako obljubljal modrega maksa, tega dal šlezijskemu poročniku Schnieberju in ne Rommlu. Schnieber je osvojil hrib Visoka glava pod vrhom Matajurja in o tem sporočil po radijski zvezi v svojo 12. divizijo. Tam so njegov vojaški uspeh napihnili, tako da so Šlezijca pomotoma označili za osvojitelja Matajurja, za kar ga je cesar odlikoval z modrim maksom (Mährle, 2009. str. 32). 


\section{WÜRTTEMBERŠKI GORSKI BATALON IN BOJI V ITALIJI}

Po osvojitvi Matajurja se je Württemberški gorski bataljon v naslednjih dneh bojeval blizu Čedada, se prebil do kraja Ronki (Ronchis) in 28. oktobra v deževnem in oblačnem vremenu dosegel reko Ter pri mestu Primulacco. Prodor proti zahodu je uspešno nadaljeval in 30. oktobra dosegel reko Tilment. 1. novembra 1917 so Württemberški gorski bataljon priključili korpusu Krauss. 3. novembra je Sprösser govoril z generalom Dellmensingnom, ki je pohvalil delovanje Württemberškega gorskega bataljona in mu povedal, da je njegov bataljon podrejen lovski diviziji. 4. novembra se je Württemberški gorski bataljon premikal v smeri Travesia, nato pa 6. novembra proti mestoma Meduno in Chievolis, kjer so ujeli 230 italijanskih vojakov. Na poti v Chievolis je bil Sprösserjev bataljon ponovno prestavljen iz lovske v 22. divizijo, znotraj katere je bil razporejen v 42. brigado generala Mertna. Brigada in Württemberški gorski bataljon sta se iz Chievolisa usmerila proti mestu Longarone (Wilks, 2001, str. 164-165).

Württemberški gorski bataljon je tako deloval na goratem območju med rekama Meduna in Piava ter svojo pot nadaljeval v smeri prelaza Clautana. Tik pod vrhom prelaza je Sprösser od nadrejenih dobil informacijo, da bodo njegovo enoto okrepili s 1. strelskim bataljonom 42. brigade in 377. odredom gorskih havbic. To je Sprösserja samo še ohrabrilo, medtem ko je preučeval napad na prelaz, ki sta ga branili italijanski četi s številnimi mitraljezi in gorskimi topovi. Spoznal je, da bo mogoče prelaz osvojiti samo z obkolitvenim manevrom in da je strokovnjak za take manevre Rommel s 1. in 2. četo ter 1. mitralješko četo. Naloga ni bila lahka, saj je Rommel imel z obkolitvijo zaradi močnega italijanskega mitralješkega in artilerijskega ognja precej težav, zato se je moral najprej umakniti na varno razdaljo, potem pa je sklenil, da je mogoče izvesti le frontalni napad. Nočni napad na italijanske položaje se mu je predvsem zaradi časovne neusklajenosti napada njegovih čet ponesrečil, poleg tega pa je imel težave s kritjem, saj je bilo območje precej odprto. Kmalu je Sprösser dobil informacijo, da se je italijanska enota umaknila s prelaza, ker je dobila nalogo, da blokira ceste, ki so vodile proti dolini v Cimolais. Hitro je ukazal premik proti Cimolaisu, medtem pa sta Gösslerjeva in Rommlova enota dosegli prelaz ter nadaljevali pot proti krajema Claut in Cimolais. 42. brigada je Württemberškemu gorskemu bataljonu izdala povelje, da se mora ustaviti in prepustiti vodenje 1. strelskemu bataljonu, česar pa Sprösser ni upošteval z izgovorom, da je njegov bataljon neprestano v stiku z nasprotnikom, zato česa takega ne bi bilo mogoče izvesti (Wilks, 2001, str. 167-170).

Sprösserju se je mudilo priti do mesta Longarone, toda $\mathrm{z}$ bataljonom je moral osvojiti še prelaz San Osvaldo. V noči z 8. na 9. november je preučeval zemljevide in načrtoval, kako bo napredovalo vseh devet njegovih čet, toda Rommel se $\mathrm{z}$ njegovim načrtom ni strinjal, saj ni želel ponovno izpostavljati svojih utrujenih mož. Sprösser je spremenil ukaz, vendar ga je 9. novembra ponovno čakalo presenečenje. Dobil je ukaz poveljnika 42. brigade, da se mora njegov bataljon 
ustaviti v Cimolaisu in počakati na brigado. Sprösser je prejeti ukaz ponovno zavrnil in odgovoril, da so že začeli boj z nasprotnikom v smeri prelaza San Osvald in mesta Longarone, zato ni bilo mogoče, da bi se njegov bataljon ustavil. Rommlov odred je blizu Cimolaisa naletel na močan italijanski odpor. Zbral je svoje enote in pripravil načrt za napad na italijanske položaje, kar je bilo precej težko. Edina možnost je bil napad na desni strani ceste, ki bi bil podprt z močnim mitralješkim ognjem. Našel je dobro kritje za mitraljeze in napad je bil uspešen, čeprav je 1. četa zamujala na svoje položaje in nevede streljala na svoje soborce iz 3. čete, ki so že zasedli italijanske položaje. Rommel se je nato premaknil do vasi San Martino in nadaljeval pot proti Piavi in kraju Erto. Ves čas so bili v njegovi okolici umikajoči se italijanski vojaki, Rommlu pa so zelo pomagali tudi vojaki kolesarji, ki so hitro napredovali in posredovali sporočila med enotami. Ves čas so se čez mostove čez reko Piavo umikale italijanske enote, ki niso vedele, da so nemške enote že med njimi. Rommel se je z enotami povzpel na koto 882 in pod njim je bilo mesto Longarone. Zavedal se je svojega položaja in dejstva, da brigada še prihaja, prav tako prihajajo tudi preostali deli njegove enote. Imel je 1. in 3. četo ter 1. mitralješko četo, tesno za njimi pa je bil 1. strelski bataljon. Ko je Rommel prvič videl Longarone $\mathrm{z}$ okolico, so se po dolini umikale številne italijanske pehotne in topniške enote, ne da bi vedele za nasprotnikovo bližino. Rommel je s svojimi vojaki blokiral umikajoče se italijanske enote. Vezal jih je nase in jim onemogočal umik, pri čemer so mu pomagale še druge nemške ter avstro-ogrske enote. Italijani so se znašli v pasti, mesto Longarone pa je bilo obkoljeno, tako da je v mestu ostalo nekaj tisoč italijanskih vojakov, ki so jim presekali pot umika in jih zajeli.

Italijanska 4. armada je tako plačala za zamudo pri umiku. Pri mestu Longarone je bilo zajetih 10.000 vojakov, 200 mitraljezov, 18 gorskih topov in številna vojaška oprema. V Rommlovi četi je bilo med krajema Cimolais in Longarone šest mrtvih, dva sta bila hudo ranjena, 19 je bilo laže ranjenih, en vojak pa je bil pogrešan. Z zajetjem celotne 1. italijanske divizije je bila za 14. armado odprta pot do Piave in Belluna. Pri osvojitvi mesta Longarone sta imela pomembno vlogo tako Sprösser kot Rommel. Do konca operacije pri mestu Longarone je Sprösser dobil najmanj štiri ukaze od poveljnika 43. brigade, da se mora Württemberški gorski bataljon ustaviti in prepustiti vodenje napada drugim enotam 43 . brigade. Na srečo je Sprösserja podpiral poveljnik divizije general Müller, zato je bil tudi tako samozavesten in ni ubogal brigadnih ukazov. 13. decembra so Rommla in Sprösserja obvestili, da sta zaradi uspehov njune enote v 12. soški ofenzivi dobila odlikovanje pour le merite, za kar jima je čestital tudi cesar (Wilks, 2001, str. 170-184).

Württemberški gorski bataljon je 11. novembra še ostal v mestu Longarone. Pokopali so svoje padle vojake, potem pa so še šest tednov ostali v Monte Grappi, preden so zapustili Italijo. Bataljon je bil medtem največkrat uporabljen kot enota, ki je skoraj vedno delovala v konici napada. Dejstvo je, da se je 14. armada na masivu Monte Grappa spopadala s povsem drugačnim nasprotnikom, kot se je 
pri Kobaridu in Tolminu, saj so bili italijanski vojaki 4. armade dobro izurjeni v gorskem bojevanju ter zelo motivirani. Württemberški gorski bataljon je nato prodiral od mesta Longarone po dolini Piave, da bi osvojil dobro branjeno gorovje Monte Grappa. 16. novembra je bataljon prišel v mesto Feltre, naslednji dan pa je od poveljnika 1. avstro-ogrskega korpusa Kraussa dobil nalogo, da napreduje čez Monte Spinoncio v smeri Colle dell'Orso. Württemberški gorski bataljon naj bi napadel italijanske položaje na vrhu grebena med Monte Grappo in Monte Pallonom, vendar je Sprösser spremenil načrt napada in je v smer proti Colle dell'Orso čez Spinoncio poslal le Rommlov odred. Preostali deli Württemberškega gorskega bataljona naj bi prenočili v okolici Rocca Cise, naslednjega dne pa naj bi napadli pobočja Monte Grappe. Württemberški gorski bataljon je po prihodu v mesto Quero 17. novembra ponoči nadaljeval pot proti vasi Schievenin, kamor je prišel okoli polnoči. Rommlov odred je medtem napredoval čez nižino Alano proti vasi Uson v smeri Monte Spinoncie.

Sprösser je imel 18. novembra poveljniško mesto pri hribu Rocca Cisa. Rommlov odred je poslal vzhodno od Monte Spinoncie, enoto poročnika Fuchtnerja pa je poslal, da zavzame čim več italijanskih položajev, ki so bili dobro utrjeni in branjeni. Fuchtner je zavzel italijanske položaje vzhodno od Stalle Cinespe, vendar naprej ni mogel več napredovati. Medtem je Rommlov odred izvidoval smer proti hribu Spinoncia na njenem vzhodnem delu. Pokazalo se je, da so Italijani zelo dobro utrjeni in da položaje branijo z močnimi topniškimi enotami. Rommlov odred je bil hitro ustavljen in napredovanje je bilo onemogočeno. Okoli 4. ure 19. novembra so Italijani napadli tudi Fuchtnerjeve enote, vendar so se te uspešno branile in zasedle nekaj novega ozemlja. Prav tako je Rommlov odred želel prebiti italijansko obrambo pri hribu Spinoncia, vendar mu ni uspelo. 20. novembra so se Württemberškemu gorskemu bataljonu priključili še 1. polk tirolskih cesarskih strelcev, ki naj bi napadel s severovzhoda, 5. četa in bosansko-hercegovska četa z jugovzhoda. Ognjeno podporo so omogočili dve bateriji s hriba Rocca Visa in Rommlov odred z gorskima baterijama z območja okoli Monte Spinoncie. Napad je vodil major Sprösser, hkrati pa je bila na napad pripravljena tudi 25 . brigada 94. divizije v Val Stizzonu na zahodnem delu Monte Fontane Secce. Njena naloga je bila zasesti pobočja Monte Salarola in potem napredovati proti Colle dell'Orso (Wilks, 2001, str. 213-214).

21. novembra se je začel napad Sprösserjeve skupine, ki se je kmalu prebila do vrha Fontane Secce, 25. brigada v dolini Val Stizzon in Rommlov odred pa nista bila uspešna. Naslednjega dne je poveljnik 98. brigade želel nadaljevati svoje boje, vendar so tirolski cesarski strelci potrebovali čas za reorganizacijo. Rommlov odred je bil neuspešen pri prodiranju proti Monte Spinoncii in to se je zgodilo tudi preostalim enotam Württemberškega gorskega bataljona, ki so bile neuspešne $\mathrm{v}$ prodiranju proti masivu Monte Grappa v Bassani. Edini uspeh je bilo zajetje vrha Fontane Secce. Še posebno razočaran je bil Rommel, saj je bil pet dni prisiljen biti na mestu zaradi močnega italijanskega artilerijskega ognja in mu tako ni uspelo zasesti tako želene Monte Spinoncie. 
Sprösser je še vedno upal, da mu bo uspelo zasesti greben Monte Salarol, zato je 23. novembra ponovno poizkusil. Postal je poveljnik treh bataljonov tirolskih cesarskih strelcev in Württemberškega gorskega bataljona, ki mu je po novem poveljeval Rommel. Bitka naj bi se začela v zgodnjih jutranjih urah 25. novembra. Ne smemo pozabiti, da je bil Sprösser podrejen Kraussovemu korpusu, ki je bil razdeljen na skupino generala Wiedna in skupino generala Müllerja, pod čigar poveljstvo je spadala tudi Sprösserjeva skupina enot. Glavni nalogi enot generala Müllerja sta bila napredovanje čez pobočja Monte Tombe in osvojitev Monte Spinoncie ter območja med Salarolom in Fontane Secce. Naloga enot generala Wiedna je bila, da napreduje po dolini reke Brente, zasede vrhove Berretta in Asolone ter območje med Ronconejem in Pertico. Sprösserjeva skupina enot je začela napadati 25. novembra ob 8. uri. Cesarski strelci so bili kljub vztrajnim napadom na italijanske položaje neuspešni, hkrati pa se je večalo število njihovih žrtev. Württemberški gorski bataljon je bil medtem v rezervi na severovzhodnem delu grebena Fontane Secce. Nenehno ga je ogrožalo italijansko artilerijsko obstreljevanje. Okoli 12. ure sta se Rommel in Sprösser odločila, da je čas za odločno akcijo Württemberškega gorskega bataljona. Ko je Württemberški gorski bataljon prišel na območje 100 metrov pod vrhom grebena Salarol, se je Rommel odločil, da bo vrh napadel naslednjega dne, zato je poročnika Ammanna poslal v izvidovanje. Njegova naloga je bila, da izve, kje v bližini so druge nemške in avstroogrske enote. Ammann je kmalu prišel v stik z lovskim bataljonom 25. brigade. Njegovi pripadniki so mu poročali o trenutnem stanju. Salarol so še vedno držale močne italijanske enote, do takrat pa so avstro-ogrske enote doživele velike izgube pri poskusu zavzetja pomembnega vrha. Medtem ko je bil Ammann pri poveljniku lovske brigade, je slednji izvedel, da želi tudi Württemberški gorski bataljon na Monte Salarol. Württemberški gorski bataljon je namreč prečkal greben Fontana Secca-Salarol in tako prekršil ukaze, saj je prišel na operativno cono delovanja drugega bataljona in druge divizije. Enote avstro-ogrske divizije, pod poveljstvo katere je spadala 25 . brigada, so zamerile Württemberškemu gorskemu bataljonu že med operacijo Longarone, saj nadrejena poveljstva niso upoštevala njihovih zaslužnih dejanj (Wilks, 2001, str. 216-219).

Medtem je tudi Württemberški gorski bataljon dobil nov ukaz, da se spusti v Val Stizzon in se premakne v mesto Feltre. Nadaljnja naloga bataljona je bila, da zavzame Monte Salarol s severne smeri in se na levem krilu poveže s 25. brigado ter tako zapolni operativno območje delovanja med brigado in 1. polkom cesarskih strelcev. Medtem so bataljon ponovno prerazporedili iz 22. divizije v lovsko divizijo. Sprösser je Württemberškemu gorskemu bataljonu ukazal, naj zavzame greben Monte Salarol-Colle dell'Orso z obkolitvijo z zahodne strani grebena Fontana Secca in pri tem sodeluje s 25. brigado v dolini Val Stizzon. Rommel po poročanju Sprösserja ni izpolnil tega ukaza, saj je Württemberški gorski bataljon bivakiral pod Fontano Secco na njenem vzhodnem delu, Rommel pa se je šele pozneje odločil za napad v smeri Monte Salarol. Rommlova in Sprösserjeva poročila o tem, kako je Württemberški gorski bataljon deloval med napadom na Monte Salarol, se razlikujejo in dejstvo je, da je še danes veliko nejasnosti 
glede napada enot Württemberškega gorskega bataljona na ta nikdar osvojeni italijanski vrh. Napad bataljona ni bil uspešen, saj sta bila Sprösser in Rommel preveč zaverovana v svoje sposobnosti in sposobnosti svojih vojakov ter tako nista videla potrebe po tem, da bi se pri napadu na Monte Salarol povezala s preostalimi enotami. General von Below je v svojem dnevniku 25. novembra zapisal, da je bila 22. strelska divizija neuspešna pri zavzemanju kot 1385 in 1222 južno od Fontane Secce ter da ji ni uspelo napredovati. Za tako stanje je krivil Württemberški gorski bataljon, ki je nazadnje končal v globini doline Val Stizzon.

Počasno napredovanje 14. armade novembra in neuspeh pri osvojitvi grebena Monte Salarol sta napadalcem dala vedeti, da bo treba pred začetkom zime opustiti vse nadaljnje operacije proti Italijanom. Kljub temu je vrh 14. armade želel pokazati, da imajo njene enote še vedno pobudo in željo po preboju močne italijanske obrambe. Vsi nadaljnji napadi 14. armade so se slabo končali, kar je Italijanom ponovno dvignilo moralo in samozavest. Württemberški gorski bataljon je bil medtem že daleč v notranjosti za frontnimi črtami in je ostal v Bellunu do 10. decembra, potem pa je dobil ukaz, da je prerazporejen v 5. divizijo. Naslednje dni se je bataljon gibal proti dolini Schievenin in Alanu. 11. decembra je ponovno sledil napad 200. in 5. divizije na italijanske položaje na Spinoncii, Salarolu in Colle dell'Orso, vendar ni bil uspešen. Nato je 14. armada še 17. decembra načrtovala napad, v katerega naj bi bili vključeni 200. divizija z lovskimi bataljoni, Württemberški gorski bataljon, 2. bataljon 52. pehotnega polka in oba bataljona 5. divizije. Glavni cilj je bil zavzeti Monte Salarol. Napad Sprösserjeve skupine je bil težaven, saj je zaradi snega in poledice drselo, poleg tega pa so se Italijani odločno upirali. Napad zaradi slabega vremena in močnega italijanskega odpora ni bil uspešen, zato je poveljstvo divizije odločilo, da se napad konča. Vse enote 14. armade so po zadnjem neuspehu decembra 1917 končale bojne aktivnosti. Ukazano jim je bilo, da se umaknejo s Spinoncie proti Fareni, tako da je bilo bojev na grebenu Monte Grappa konec, Sprösser in Rommel pa sta že bila na poti $\mathrm{v}$ Nemčijo (Wilks, 2001, str. 216-225).

Sklep Württemberški gorski bataljon je bil ena najuspešnejših nemških enot med prvo svetovno vojno. Odlikovanje württemberških častnikov nižjih činov, kot sta bila Theodor Sprösser in Erwin Rommel, z modrim maksom je bilo do leta 1917 redko in je že zato pomenilo nekaj posebnega. Dejstvo, da sta major in nadporočnik, ki sta poleg tega pripadala isti enoti, torej Württemberškemu gorskemu bataljonu, dobila to visoko odlikovanje, dokazuje, da so bili njuni vojaški uspehi in uspehi celotne enote po mnenju sodobnikov izjemni. Priznanje za vojaške dosežke se je mlademu nadporočniku Rommlu obrestovalo tudi poklicno. Medtem ko je Sprösser vodil gorski bataljon do maja 1918, ko je bil težko ranjen v bitki za Chemin des Dames, je bil Rommel v začetku februarja leta 1918 premeščen na štabno funkcijo. V zadnjih mesecih vojne je mladi, po oceni württemberškega vojnega ministrstva izjemno sposobni častnik (Mährle, 2009, str. 36) na tej funkciji, ki jo je sicer zelo nerad prevzel, med drugim dobil tudi priložnost, da kot vojaški strokovnjak nastopi pred strokovno javnostjo. 
1. Landesarchiv Baden Württemberg - Abteilung Hauptstaatsarchiv Stuttgart (HStAS):

2. HStAS, 1-M130, Bü53, Deutsches Alpenkorps, Marschgruppe III, Marschbefehl, 14. Oktober 1917,

3. HStAS, 2 - M130, Bü 53, Württemberg Gebirgs Bataillon, Bataillonsbefehl, 14. Oktober 1917

4. HStAS, 3-M130, Bü53, Württemberg Gebirgs Bataillon, Besondere Anordnungen, 14. Oktober 1917,

5. HStAS, 4-M130, Bü53, Gefechts-Bericht 24.-31. Oktober 1917, str. 1.

6. HStAS, 5-M411, Bd 2115, Kriegstagebuch 11, Oktober 1917-26. Februar 1918.

7. Bull, S., 2014. Stosstruptaktik: German Assault Troops of the First World War. Stroud Gloucestershire: Spellmount.

8. Galić, L., 2005. Od Krna do Rombona 1915-1917. Tolmin: Tolminski muzej.

9. Galić, L., Marušič, B., 2005. Tolminsko mostišče 1. Tolmin: Tolminski muzej.

10. Gaspari, P., 2012. La verita su Caporetto. Udine: Gaspari editore.

11. Hunzeker, M. A., 2013. Perfecting War. Princeton: Princeton University.

12. Mährle, W., 2009. Erwin Rommel und das Württembergische Gebirgsbataillon in der 12. Isonzo-Schlacht - Wahrnehmung und Deutung eines militärischen Erfolgs. V Erwin Rommel. Geschichte und Mythos (Stuttgarter Symposion, Schriftenreihe, Bd. 13). Karlsruhe: Braun, str. 17-53.

13. Reiss, R., 1931. Das Königlich Bayerische Infanterie-Leibregiment im Weltkrieg 1914/1918, Anlage 6. München: Berlegt bei Max Schid.

14. Rommel, E., 2013. Infantry Attacks. Barnsley: Greenhill Books.

15. Rommel, E., 1997. Preboj pri Tolminu 1917. Kobarid: Kobariški muzej.

16. Sprösser, T., 1933. Geschichte der Württembergischen Gebirgsschützen. Stuttgart: Belser Verlagsbuchhandlung.

17. Wilks, J.\&E., 2001. Rommel and Caporetto. Barnsley: Leo Cooper. 
Zemljevid št. 1:

$68 \mathrm{i}-1$ Wuerttbg

5 - WGB 36

Vormach

Pot 14. armade

in Württember-

škega gorskega

bataljona na

soško bojišče

Vir:

Sprösser,

T., 1933.

Map 1:

$68 \mathrm{i}-1$ Wuerttbg

5 - WGB 36

Vormach

Advance of the

$14^{\text {th }}$ Army and

Würtemberg

Battalion to the

Isonzo Front

Source:

Sprösser,

T., 1933

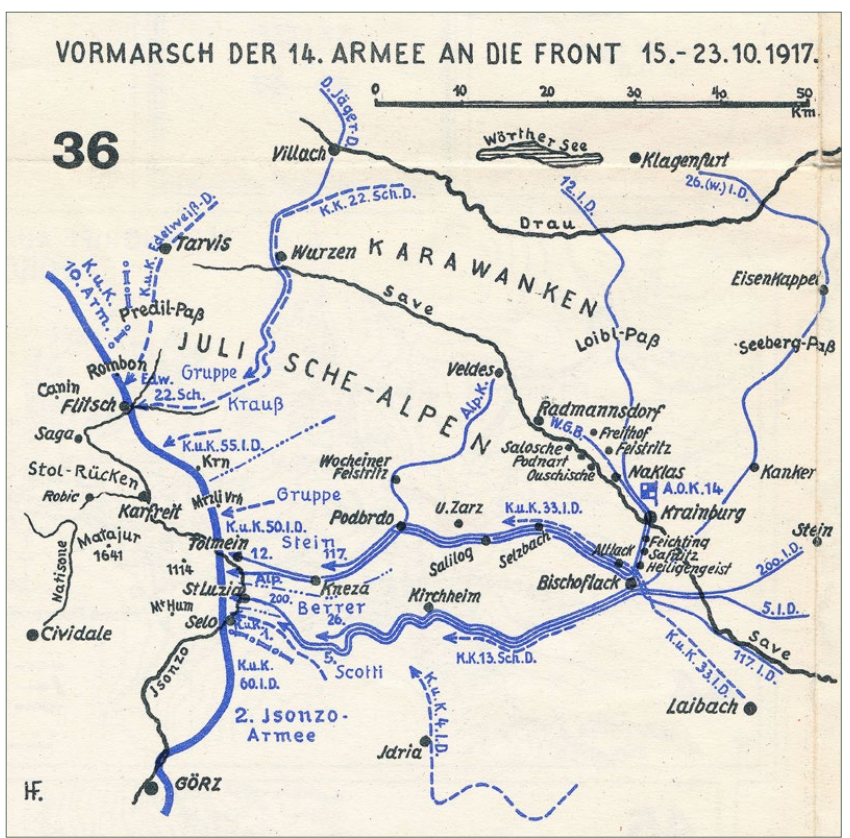

Zemljevid št. 2: 68i - 1 Wuerttbg 5 - WGB 38 Kolovrat Boji Württemberškega gorskega bataljona in drugih enot alpskega korpusa 24. oktobra 1917

Vir:

Sprösser, T., 1933.

Map 2:

68i - 1 Wuert-

tbg 5 - WGB

38 Kolovrat

Battles of the Württemberg Mountain Battalion and other Alpine Corps units on 24 October 1917 Source: Spröser, T., 1933
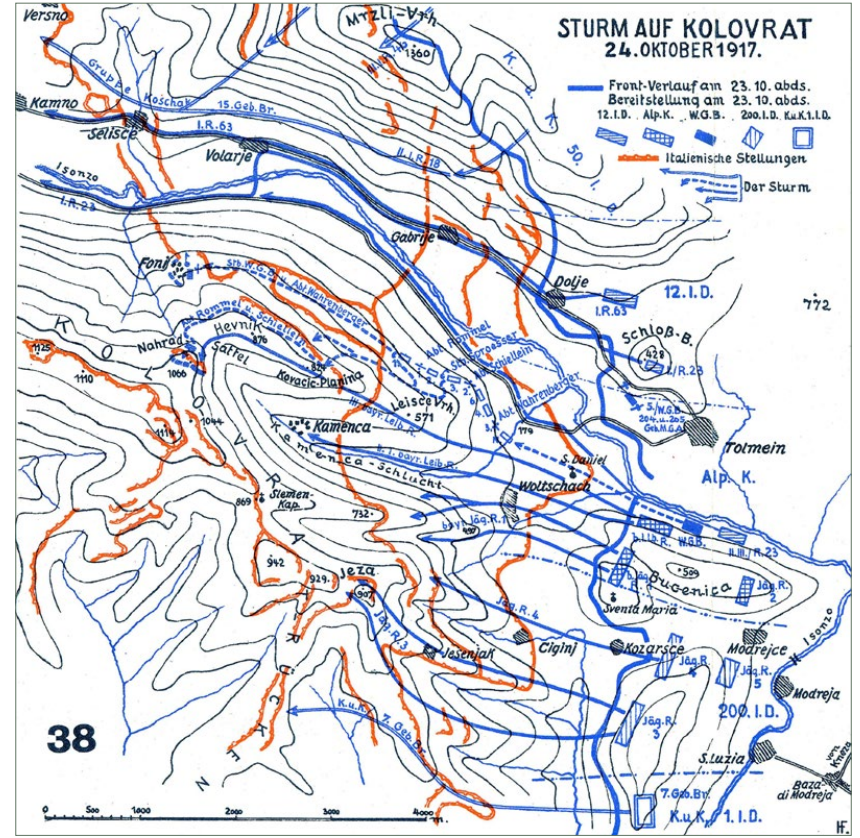